\title{
Effect of Silicon Application on Incidence Yellow Stem Borer, Scirpophaga incertulas (Walker) in Rice
}

\author{
S. D. Patel* and P. K. Borad \\ Directorate of Extension Education, Anand Agricultural University, Anand, Gujarat, India \\ *Corresponding author
}

\section{A B S T R A C T}

\section{Keywords}

Rice, Yellow stem borer, Silicon, Scirpophaga incertulas

\section{Article Info}

Accepted:

18 March 2021

Available Online:

10 April 2021
The yellow stem borer, Scirpophaga incertulas (Walker) (Lepidoptera: Pyralidae) is one of the major pests in all rice-growing regions of India. An experiment was conducted at Agricultural Research Station, Anand Agricultural University, Derol, Dist. Panchmahal, Gujarat, India during kharif(rainy) season in 2011 and 2012 to know the effect of soil and foliar application of silicon on the incidence of yellow stem borer, S. incertulas in rice. Four doses of calcium silicate (500, 1000, 1500 and $2000 \mathrm{~kg} / \mathrm{ha}$ ) applied as soil application and three concentrations of potassium silicate $(0.5,1.0$ and 2.0 per cent) applied as foliar sprays were evaluated along with control. Soil application of calcium silicate @ 1500 and $2000 \mathrm{~kg} / \mathrm{ha}$ significantly reduced dead heart and white ear head damage due to yellow stem borer, $S$. incertulas in rice. These treatments also increased grain and straw yield of rice.

\section{Introduction}

Rice(Oryza sativa Linnaeus) is a staple food for more than half of the world's population. Asia is considered to be a "Rice Bowl" of the world occupying 90 per cent of the world's rice area. China and India are the two largest rice-producing countries. Rice is attacked by more than 100 species of insects, of which about 20 are major pests (Pathak and Saxena, 1980). Among the various insect pest inflicting yield losses, the yellow stem borer,
Scirpophaga incertulas (Walker) (Lepidoptera: Pyralidae) is one of the major pests in all rice-growing regions of India (Chelliah et al., 1989). Larval feeding and subsequent internodal penetration during vegetative and reproductive stage cause severing of the growing apical plant part and finally results in the characteristic symptom of dead heart and white ear head at the vegetative and reproductive growth stage of rice plant, respectively (Satpathi et al., 2012). S. incertulascan cause yield losses ranging from 
3-95 per cent (Ghose et al., 1960), while Prasad et al., (2007) reported yield losses ranging from 38-50 per cent.

Insecticides are widely used to manage rice pests including $S$. incertulas. However, the continuous use of a wide range of insecticides has caused many adverse effects. Hence, there is a need to find a suitable alternative to the chemical method of insect control. Insect pest damage may also be reduced through careful management of nutrient requirements of the crop or amendments with mineral nutrients, such as silicon ( $\mathrm{Si})$, that reduce crop susceptibility to pests (Meyer and Keeping, 2005). Hosseini et al., (2011) reported a decrease in white ear head damage due to striped rice stem borer, Chilo suppressalis with an application of silica. Very few workers have studied the effect of silicon application on the incidence of S.incertulas in rice in India and such studies have not been reported from Gujarat. Hence, it was thought worthwhile to conduct an investigation on the impact of soil and foliar application of silicon on the incidence of S.incertulas.

\section{Materials and Methods}

The present study was conducted at Agricultural Research Station, Anand Agricultural University, Derol, Dist. Panchmahal (Gujarat) during kharif (rainy) season for two successive years i.e., 2011 and 2012. The experiment was laid out in Randomized Block Design with eight treatments and three replications using rice variety GR-11. Initially, rice seedling were raised in the nursery for 25 to 30 days. Later on, seedlings were transplanted at a spacing of $20 \times 15 \mathrm{~cm}$ in the experimental plot. The gross plot and net plot size was $3.90 \times 3.20 \mathrm{~m}$ and 3.00 and $2.40 \mathrm{~m}$, respectively. Four doses $(500,1000,1500$ and $2000 \mathrm{~kg} / \mathrm{ha})$ of soil application (SA) of calcium silicate $\left(\mathrm{CaSiO}_{3}\right)$ and three concentrations $(0.5,1.0$ and $2.0 \%)$ of foliar application (FA) of potassium silicate $\left(\mathrm{K}_{2} \mathrm{SiO}_{3}\right)$ along with control were evaluated for their impact on the incidence of yellow stem borer, $S$. incertulas. Calcium silicate was applied into soil at the time of transplanting, whereas potassium silicate was applied as a foliar spray at 30, 45 and 60 days after transplanting. Spray application was carried out with knapsack sprayer fitted with a hollow cone nozzle. The volume of the spray solution used was 500 litres per ha. All recommended agronomical practices were followed to raise the rice crop. Calcium silicate $(\mathrm{CaSiO} 3)$ contains 24 per cent silicon, whereas potassium silicate $(\mathrm{K} 2 \mathrm{SiO} 3)$ contains 18 per cent silicon.

The observations on tiller damage by yellow stem borer, $S$. incertulas were recorded from the ten hills selected randomly from each net plot area. For this purpose, total tillers and dead hearts were counted at 30 and 45 days after transplanting (DATP), whereas total tillers and white ear heads were counted at 60 and 75 DAT. Based on this counts per cent dead hearts and white ear heads were calculated. Rice crop was harvested on maturity and it was allowed for sun drying in field for 2-3 days. Thereafter, it was threshed and cleaned manually. The grains and straw of each net plot were weighed separately. The yield obtained per plot was converted into $\mathrm{kg} / \mathrm{ha}$.

\section{Results and Discussion}

\section{Effect of Silicon Application on Incidence of S. incertulas}

The data on per cent dead hearts and white ear heads are presented in Table 1.

\section{Dead hearts}

During the first year of study, the pooled data of per cent dead hearts indicated the 
significant difference among various treatments (Table 1). Among the different treatments, the SA of calcium silicate @ 2000 $\mathrm{kg} / \mathrm{ha}$ was the most effective with 1.21 per cent dead hearts and it was at par with SA of calcium silicate@1500 kg/ha (1.52\%), 1000 $\mathrm{kg} / \mathrm{ha}(1.66 \%)$ and $500 \mathrm{~kg} / \mathrm{ha}(1.83 \%)$. Foliar application of potassium silicate $(0.5,1.0$ and $2.0 \%)$ was not effective in reducing dead hearts in rice against $S$. incertulasas they were at par with control $(3.08 \%)$.

During the second year, differences between treatments with respect to per cent dead hearts were significant (Table 1). Here also, the treatment of SA of calcium silicate @ 2000 $\mathrm{kg} / \mathrm{ha}$ recorded the lowest dead hearts $(1.36$ $\%)$ and it was at par calcium silicate @ 1500 $\mathrm{kg} / \mathrm{ha}(1.65 \%)$. Calcium silicate @ 1000 $\mathrm{kg} / \mathrm{ha}(2.25 \%)$ and $500 \mathrm{~kg} / \mathrm{ha}(2.68 \%)$ were equally effective against yellow stem borer, but they were inferior to the most effective treatment. Foliar application of potassium silicate at 0.5 to 2.0 per cent registered 3.20 to 3.37 per cent dead hearts. However, these treatments failed to give significant protection against stem borer and they were at par with control $(3.40 \%)$.

The overall pooled analysis revealed significant differences among treatments (Table 1). Significantly lowest dead hearts $(1.28 \%)$ was recorded in the treatment of SA of calcium silicate @ $2000 \mathrm{~kg} / \mathrm{ha}$ and it was at par with calcium silicate @ $1500 \mathrm{~kg} / \mathrm{ha}(1.59$ $\%)$. SA of calcium silicate @ 1000 and 500 $\mathrm{kg} / \mathrm{ha}$, noticed 1.94 and 2.24 per cent dead hearts, respectively. SA of calcium silicate @ $1000 \mathrm{~kg} / \mathrm{ha}$ was equally effective as calcium silicate@ 1500 and $500 \mathrm{~kg} / \mathrm{ha}$, whereas the lowest dose of calcium silicate $(500 \mathrm{~kg} / \mathrm{ha})$ was at par with foliar application of potassium silicate@ 2.0 per cent, in reducing the dead hearts due to $S$. incertulas in rice. Foliar application of potassium silicate @ 0.5 to 2.0 per cent recorded 2.81 to 3.15 per cent dead hearts, but they were at par with control (3.24 $\%)$.

\section{White ear heads}

In the first year, there were significant differences among the treatments with respect to per cent white ear heads (Table 1).

Significantly lowest $(2.91 \%)$ white ear heads was observed in the treatment of SA of calcium silicate@2000 kg/ha and it was at par with SA of calcium silicate @ $1500 \mathrm{~kg} / \mathrm{ha}$ $(3.28 \%), 1000 \mathrm{~kg} / \mathrm{ha}(3.89 \%)$. The lowest dose $(500 \mathrm{~kg} / \mathrm{ha})$ of calcium silicate noticed 4.42 per cent white ear heads and it was equally effective as calcium silicate @ 1000 and $1500 \mathrm{~kg} / \mathrm{ha}$ in protecting the crop against $S$. incertulas. Foliar application of potassium silicate @ 0.5, 1.0 and 2.0 per cent recorded 6.43, 5.78 and 5.45 per cent white ear heads, respectively. Furthermore they were at par with control $(6.93 \%)$.

During the second year, the differences among various treatments were significant. The lowest $(2.61 \%)$ white ear heads was observed in the treatment of SA of calcium silicate @ $2000 \mathrm{~kg} / \mathrm{ha}$ and it remained at par with SA of calcium silicate@1500 kg/ha (3.10\%) and @ $1000 \mathrm{~kg} / \mathrm{ha}(3.72 \%)$. SA of calcium silicate @ $500 \mathrm{~kg} / \mathrm{ha}$ noticed 4.08 per cent white ear heads and it was equally effective as SA of calcium silicate@1000 and 1500 kg/ha. All three concentrations of foliar application of potassium silicate exhibited 4.66 to 5.46 per cent white ear heads but they were at par with control $(6.00 \%)$.

The data pooled over periods and years revealed significant differences among the treatments (Table 1). The lowest $(2.76 \%)$ white ear heads was noticed in the plots treated with calcium silicate @ 2000 kg/ha and it was at par with SA of calcium silicate @ $1500 \mathrm{~kg} / \mathrm{ha}(3.19 \%)$. 
Table.1 Effect of silicon application on dead hearts and white ear heads due to of S. incertulas in rice

\begin{tabular}{|c|c|c|c|c|c|c|c|}
\hline \multirow{2}{*}{\multicolumn{2}{|c|}{ Treatments }} & \multicolumn{3}{|c|}{ Dead hearts (\%) } & \multicolumn{3}{|c|}{ White ear heads (\%) } \\
\hline & & 2011 & 2012 & Pooled & 2011 & 2012 & Pooled \\
\hline \multirow{2}{*}{\multicolumn{2}{|c|}{ SA of calcium silicate @ $500 \mathrm{~kg} / \mathrm{ha}$ at TP }} & 7.78ab & $9.43 \mathrm{~cd}$ & $8.60 \mathrm{~cd}$ & $12.14 \mathrm{bc}$ & $11.65 \mathrm{bcd}$ & $11.89 \mathrm{~cd}$ \\
\hline & & $(1.83)$ & $(2.68)$ & $(2.24)$ & $(4.42)$ & $(4.08)$ & $(4.25)$ \\
\hline \multirow{2}{*}{\multicolumn{2}{|c|}{ SA of calcium silicate @ $1000 \mathrm{~kg} / \mathrm{ha}$ at TP }} & $7.40 \mathrm{a}$ & $8.62 \mathrm{bc}$ & $8.01 \mathrm{bc}$ & $11.38 \mathrm{ab}$ & $11.12 \mathrm{abc}$ & $11.25 b c$ \\
\hline & & $(1.66)$ & $(2.25)$ & $(1.94)$ & $(3.89)$ & $(3.72)$ & $(3.80)$ \\
\hline \multirow{2}{*}{\multicolumn{2}{|c|}{ SA of calcium silicate @ $1500 \mathrm{~kg} / \mathrm{ha}$ at TP }} & $7.09 a$ & 7.39ab & $7.24 \mathrm{ab}$ & $10.44 a b$ & $10.14 \mathrm{ab}$ & $10.29 \mathrm{ab}$ \\
\hline & & $(1.52)$ & $(1.65)$ & $(1.59)$ & $(3.28)$ & $(3.10)$ & $(3.19)$ \\
\hline \multirow{2}{*}{\multicolumn{2}{|c|}{ SA of calcium silicate @ $2000 \mathrm{~kg} / \mathrm{ha}$ at TP }} & $6.31 \mathrm{a}$ & $6.70 \mathrm{a}$ & $6.51 \mathrm{a}$ & $9.83 a$ & $9.30 \mathrm{a}$ & $9.56 \mathrm{a}$ \\
\hline & & $(1.21)$ & $(1.36)$ & $(1.28)$ & $(2.91)$ & $(2.61)$ & $(2.76)$ \\
\hline \multirow{2}{*}{\multicolumn{2}{|c|}{$\begin{array}{l}\text { FA of potassium silicate } 0.5 \% \text { at } 30,45 \text { and } \\
60 \text { DATP }\end{array}$}} & $9.87 \mathrm{c}$ & $10.57 d$ & $10.22 \mathrm{e}$ & $14.69 \mathrm{~d}$ & $13.52 \mathrm{de}$ & 14.10ef \\
\hline & & $(2.94)$ & $(3.37)$ & $(3.15)$ & $(6.43)$ & $(5.46)$ & $(5.94)$ \\
\hline \multirow{2}{*}{\multicolumn{2}{|c|}{$\begin{array}{l}\text { FA of potassium silicate } 1.0 \% \text { at } 30,45 \text { and } \\
60 \text { DATP }\end{array}$}} & $9.35 c$ & $10.50 \mathrm{~d}$ & $9.93 \mathrm{e}$ & $13.91 \mathrm{~cd}$ & $13.34 \mathrm{de}$ & $13.62 \mathrm{ef}$ \\
\hline & & $(2.64)$ & $(3.32)$ & $(2.97)$ & $(5.78)$ & $(5.32)$ & $(5.55)$ \\
\hline \multirow{2}{*}{\multicolumn{2}{|c|}{$\begin{array}{l}\text { FA of potassium silicate } 2.0 \% \text { at } 30,45 \text { and } \\
60 \text { DATP }\end{array}$}} & $9.01 \mathrm{bc}$ & $10.31 d$ & 9.66de & $13.50 \mathrm{~cd}$ & $12.47 \mathrm{cde}$ & $12.98 \mathrm{de}$ \\
\hline & & $(2.45)$ & $(3.20)$ & $(2.81)$ & $(5.45)$ & $(4.66)$ & $(5.05)$ \\
\hline \multirow{2}{*}{\multicolumn{2}{|c|}{ Control }} & $10.11 \mathrm{c}$ & $10.62 d$ & $10.36 \mathrm{e}$ & $15.29 a$ & $14.18 \mathrm{e}$ & $14.74 \mathrm{f}$ \\
\hline & & $(3.08)$ & $(3.40)$ & $(3.24)$ & $(6.96)$ & $(6.00)$ & $(6.47)$ \\
\hline \multirow[t]{7}{*}{ S. Em. \pm} & Treatment $(\mathbf{T})$ & 0.47 & 0.48 & 0.36 & 0.80 & 0.61 & 0.40 \\
\hline & Period $(\mathrm{P})$ & 0.24 & 0.24 & 0.18 & 0.28 & 0.30 & 0.20 \\
\hline & Year $(Y)$ & - & - & 0.18 & - & - & 0.20 \\
\hline & $\mathrm{T} \times \mathrm{P}$ & 0.67 & 0.68 & 0.51 & 0.79 & 0.86 & 0.57 \\
\hline & $\mathrm{T} \times \mathrm{Y}$ & - & - & 0.51 & - & - & 0.57 \\
\hline & $\mathrm{P} \times \mathrm{Y}$ & - & - & 0.25 & - & - & 0.28 \\
\hline & $\mathrm{T} \times \mathrm{P} \times \mathrm{Y}$ & - & - & 0.72 & - & - & 0.80 \\
\hline C.V. \% & & 13.87 & 12.68 & 14.15 & 10.75 & 12.47 & 11.29 \\
\hline
\end{tabular}


Table.2 Effect of silicon application on yield of rice

\begin{tabular}{|c|c|c|c|}
\hline \multicolumn{2}{|c|}{ Treatments } & $\begin{array}{c}\text { Grain yield } \\
\text { (kg/ha) }\end{array}$ & $\begin{array}{c}\text { Straw yield } \\
(\mathrm{kg} / \mathrm{ha})\end{array}$ \\
\hline \multicolumn{2}{|c|}{ SA of calcium silicate @ $500 \mathrm{~kg} / \mathrm{ha}$ at TP } & $4545 \mathrm{bc}$ & $5211 \mathrm{ab}$ \\
\hline \multicolumn{2}{|c|}{ SA of calcium silicate @ $1000 \mathrm{~kg} / \mathrm{ha}$ at TP } & $4820 \mathrm{ab}$ & $5423 \mathrm{a}$ \\
\hline \multicolumn{2}{|c|}{ SA of calcium silicate @ $1500 \mathrm{~kg} / \mathrm{ha}$ at TP } & 4922ab & $5514 a$ \\
\hline \multicolumn{2}{|c|}{ SA of calcium silicate @ $2000 \mathrm{~kg} / \mathrm{ha}$ at TP } & $5015 a$ & $5690 \mathrm{a}$ \\
\hline \multicolumn{2}{|c|}{ FA of potassium silicate $0.5 \%$ at 30,45 and 60 DATP } & $4084 d$ & $4662 c$ \\
\hline \multicolumn{2}{|c|}{ FA of potassium silicate $1.0 \%$ at 30,45 and 60 DATP } & $4119 \mathrm{~cd}$ & $4734 c$ \\
\hline \multicolumn{2}{|c|}{ FA of potassium silicate $2.0 \%$ at 30,45 and 60 DATP } & $4156 \mathrm{~cd}$ & $4803 \mathrm{bc}$ \\
\hline \multicolumn{2}{|c|}{ Control } & 4056d & $4533 \mathrm{c}$ \\
\hline \multirow[t]{3}{*}{ S. Em. \pm} & $\mathrm{T}$ & 135.88 & 148.19 \\
\hline & $\mathrm{Y}$ & 67.94 & 74.09 \\
\hline & $\mathrm{T} \times \mathrm{Y}$ & 192.17 & 209.57 \\
\hline C.V. \% & & 7.45 & 7.16 \\
\hline
\end{tabular}

The SA of calcium silicate @ 1500 and 1000 $\mathrm{kg} / \mathrm{ha}(3.80 \%)$ were equally effective against $S$. incertulasin rice. Similarly, the SA of calcium silicate@ 1000 and 500 kg/ha (4.25 $\%$ ) were equally effective. Among the different concentrations of foliar spray potassium silicate, the highest $(5.94 \%)$ white ear heads was observed in the treatment of 0.5 per cent and it was at par with 1 per cent (5.55 $\%)$ and control (6.47\%).

The above results are in line with the results of Sasamoto (1961) who found a decrease in the susceptibility to the stem borer, $C$. Suppressalis when rice was grown in silicon supplied soils. Panda et al., (1975) observed that the larvae of the yellow rice borer, $S$. incertulas were unable to attack resistant rice plants because of the high silica content of their stems. Hosseini et al., (2011) showed that there was a decrease in white head damage with an increase in silica application rate in rice.

\section{Effect of Silicon Application on Yield of Rice}

The grain and straw yield of rice was recorded during both years of study; their data are presented in Table 2.

\section{Grain yield}

The data on grain yield, pooled over years, revealed significant differences among treatments (Table 2). All four doses (500 to $2000 \mathrm{~kg} / \mathrm{ha}$ ) of calcium silicate recorded significantly higher grain yield as compared to control plots.

The highest $(5015 \mathrm{~kg} / \mathrm{ha})$ grain yield was obtained in the treatment of calcium silicate @ $2000 \mathrm{~kg} / \mathrm{ha}$ and it remained at par with calcium silicate@1500 kg/ha (4922 kg/ha) and $1000 \mathrm{~kg} / \mathrm{ha}(4820 \mathrm{~kg} / \mathrm{ha})$. All three concentrations $(0.5,1.0$ and $2.0 \%)$ of potassium silicate produced grain yield between 4084 and $4156 \mathrm{~kg} / \mathrm{ha}$, but they were 
at par with control (4056 kg/ha).

\section{Straw yield}

The data on straw, yield pooled over years, indicated significant differences among treatments (Table 2). Plots applied with four different doses of calcium silicate registered significantly higher straw yield of rice as compared control. The highest $(2000 \mathrm{~kg} / \mathrm{ha})$ dose of calcium silicate yielded $5690 \mathrm{~kg} / \mathrm{ha}$ straw of rice and it was at par with the remaining three doses (1500, 1000 and 500 $\mathrm{kg} / \mathrm{ha})$. All three concentrations of potassium silicate $(0.5,1.0$ and $2.0 \%)$ produced the straw yield between 4662 and $4803 \mathrm{~kg} / \mathrm{ha}$, however, they were at par with control (4533 $\mathrm{kg} / \mathrm{ha})$.

Present findings tally the results of Singh et al., (2006), who reported that the application of silicon increased grain and straw yield of rice. The highest grain and straw yield was obtained with $180 \mathrm{~kg}$ silicon/ha, but it was at par with $120 \mathrm{~kg} / \mathrm{ha}$. Jawahar and Vaiyapuri (2010) observed that increasing levels of silicon increased the grain and straw yield of rice up to $120 \mathrm{~kg} / \mathrm{ha}$. The grain yield in the treatment of silicon@120 kg/ha was 17.14 per cent higher than control. Jawahar et al., (2015) reported that the application of calcium silicate @ $2000 \mathrm{~kg} / \mathrm{ha}$ to rice increased grain and straw yield of rice by 13.40 and 12.61 per cent, respectively.

\section{Acknowledgement}

The first author sincerely acknowledges the support provided by the Director of Research and Dean, Post Graduate Studies, Anand Agricultural University, Anand, Gujarat. The author is also thankful to the Unit Head, Agricultural Research Station, Anand Agricultural University, Derol, Dist. Panchmahal, Gujarat for providing all the necessary facilities during study.

\section{References}

Chelliah, A., Benthur, J. S. and Prakasa Rao, P. S., (1989). Approaches to rice management - Achievements and opportunities. Oryzae, 26: 12-26.

Ghose, R. L. M., Ghatge, M. B. and Subramanyan, V. (1960). Rice in India. Revised Edition. Indian Council of Agricultural Research, New Delhi, pp 74.

Hosseini, S. Z., Babaeian Jelodar, N. A. and Bagheri, N. A. (2011). Effect of silica on morphological traits and resistance of rice to striped stem borer (Chilosuppressalis Walker). Plant Ecophysioly, 3: 95-100.

Jawahar, S. and Vaiyapuri, V. (2010). Effect of sulphur and silicon fertilization on growth and yield of rice. International Journal of Current Research,9 (1): 3638.

Jawahar, S., Vijayakumar, D, Bommera, R., Jain, N. and Jeevanandham. (2015). Effect of Silixol granules on growth and yield of Rice. International Journal of Current Research and Academic Review, 3 (1): 168-174.

Meyer, J. H. and Keeping, M. G. (2005). Nitrogen and silicon impact on the resistance of sugarcane to Eldanasaccharina stalk borer (Lepidoptera :Pyralidae). In : III Silicon in Agriculture Conference, Uberlandia, $22-26$ October 2005, Brazil.

Panda, N., Pradhan, B., Samalo, A. P. and Rao, P. S. P. (1975). Note on the relationship of some biochemical factors with the resistance in rice varieties to yellow rice borer. Indian Journal of Agricultural Sciences, 45: 499-501.

Pathak, M. D. and Saxena, R. C. (1980). Breeding approaches in rice. In: Smith H. (ed.) Breeding plants resistant to 
insects. Pergamon, Oxford, pp. 61-81.

Prasad, S. S., Gupta, P. K. and Kanaujia, B. L. (2007). Simulation study on yield loss due to Scirpophaga incertulas on semi deep water rice. Annals of Plant Protection Sciences, 15: 491-492.

Sasamoto, K. (1961). Resistance of the rice plant applied with silicate and nitrogenous fertilizers to the rice stem borer, Chilosuppressalis Walker. In : Proceedings of the Faculty of Liberal Arts and Education, Vol. 3., Yamanasaki University, Japan.

Satpathi, C. R., Chakraborty, K., Shikari, D. and Acharjee, P. (2012). Consequences of feeding by yellow stem borer (Scirpophaga incertulas Walk.) on rice cultivar Swarnamashuri(MTU 7029). World Applied Sciences Journal,17 (4): 532-539.

Singh, K., Singh, R., Singh, J. P., Singh, Y. and Singh, K. K. (2006). Effect of level and time of silicon application on growth, yield and its uptake by rice (Oryza sativa). Indian Journal of Agricultural Sciences, 76 (7): 410 413.

\section{How to cite this article:}

Patel, S. D. and Borad, P. K. 2021. Effect of Silicon Application on Incidence Yellow Stem Borer, Scirpophaga incertulas (Walker) in Rice. Int.J.Curr.Microbiol.App.Sci. 10(04): 750756. doi: https://doi.org/10.20546/ijcmas.2021.1004.077 